\title{
Dual polarity magnetizations from the Upper Devonian McAras Brook Formation, Nova Scotia, and their implications for the North American apparent polar wander path
}

\author{
CAROLA STEARNS and ROB VAN DER VOO \\ Department of Geological Sciences, The University of Michigan, Ann Arbor, MI 48109-1063 (U.S.A.)
}

(Received February 23, 1988; revised version accepted May 3, 1988)

\begin{abstract}
Stearns, C. and Van der Voo, R., 1988. Dual polarity magnetizations from the Upper Devonian McAras Brook Formation, Nova Scotia, and their implications for the North American apparent polar wander path. Tectonophysics, 156: 179-191.
\end{abstract}

Thermal demagnetization of 57 samples from four lava flows of the Upper Devonian McAras Brook Formation, sampled along the Northumberland Strait in northern Nova Scotia, has yielded complex paleomagnetic results. Samples from three of the four lava flows revealed two superimposed sets of magnetic directions $(D / I=33 /-2$ and $D / I=7 /-23$, both tilt-corrected) that both appear to be Paleozoic in age. The corresponding paleopole for the northeasterly direction is similar to previously published Devonian poles for North America. Although the age of this component cannot be constrained by a field stability test, the presence of stratigraphically separated dual polarities supports a primary age for the magnetization. Application of the structural correction (strike and dip of the beds $=214 / 36 \mathrm{NW}$ ) does not significantly change the direction $(32 /-1$, in-situ vs. $33 /-2$, tilt-corrected). The paleopole for this direction is located at $35^{\circ} \mathrm{N}, 76^{\circ} \mathrm{E}$.

The additional and more northerly direction can be seen in samples from two lava flows. In this set of directions, both polarities occur without apparent stratigraphic separation. The corresponding paleopoles for this direction $\left(46^{\circ} \mathrm{N}\right.$, $116^{\circ} \mathrm{E}$, in situ, $32^{\circ} \mathrm{N}, 109^{\circ} \mathrm{E}$, tilt corrected) are similar to published Permian and Devonian paleopoles for North America, respectively. Again, the age cannot be constrained by a field test. Although the in-situ pole plots near the Permian paleopoles, Permian magnetizations are not expected to show dual polarities because of the long Kiaman reversed interval. We therefore interpret it to be pre-Kiaman. Because the tilt-corrected paleopole is near Devonian paleopoles, we tentatively interpret the northerly component as secondary (Late Devonian), but acquired before tilting of the rocks.

Our results show the same longitudinal distribution as that of the previously published Devonian paleopoles for North America. Although some authors have suggested that this spread is due to local tectonic rotation, the dispersion in our data cannot be explained by tectonic rotation. Instead, we conclude that the magnetizations of the McAras Brook Formation were acquired over a long period of time during the post-Acadian infilling of a rift basin and that the longitudinal distribution of the paleopoles was caused by the clockwise rotation of the North American plate as a whole during the Devonian. Magnetization acquisition over a long time interval is supported by the presence of dual polarities seen within individual samples.

Finally, samples from the second highest lava flow of the McAras Brook Formation revealed univectorial magnetic directions $(D / I=269 /-34$, in situ, 240/-58, tilt-corrected) that are difficult to explain because the corresponding paleopole is dissimilar to any existing Phanerozoic pole for North America. Because these directions cannot be explained by remagnetization or by tectonic rotation, we tentatively ascribe them to a transitional field direction recorded during a reversal. 


\section{Introduction}

In recent reviews of North American paleomagnetism several authors (Kent and May, 1987; Hillhouse and McWilliams, 1987; and Van der Voo, 1988) point out that there is a renewed interest in the available cratonic reference poles that can be used to construct Apparent Polar Wander Paths. Recent documentation of widespread remagnetization in the Late Paleozoic has decreased the number of reliable early and middle Paleozoic paleopoles. Only eight possible Devonian paleopoles are available for all of North America and many of these are poorly constrained (Stearns and Van der Voo, 1987). Statistically conclusive field tests, for instance, are needed to constrain the age of the magnetization, but exist for only five of these paleopoles. Although the locations of the eight pole positions are constrained in latitude (from $20-35^{\circ} \mathrm{N}$ ), there remains a large spread in longitude $\left(40^{\circ}\right)$. Moreover, the large amount of dispersion in the distribution of Devonian paleopoles is unlikely to be the result of non-averaged secular variation. Rather, the spread in longitude is due to either local tectonic rotation (e.g. Miller and Kent, 1986a, b) or apparent polar wander because of variation in the ages of acquisition of the magnetization. Since the field tests bracket the age of the magnetization only relative to a folding or intrusive event, it remains difficult to distinguish small age differences in paleopoles from this time period.

The purpose of this investigation was to gather Late Devonian paleomagnetic data from the McAras Brook Formation and to compare the results to recently published data from cratonic North America (Miller and Kent, 1986a, b; Dankers, 1982). The absence of conclusive field tests leaves the age of acquisition of magnetization in the McAras Brook Formation unconstrained. Therefore our results will not pass quality criteria needed for cratonic reference poles (Van der Voo, 1988). It is possible, however, that our results may be the first available Late Devonian results from the Avalon terrane. More importantly, the results indicate that some of the scatter seen in the available Devonian paleopoles for North America is due to apparent polar wander and not to local tectonic rotation.

\section{Geology and sampling}

In the northern Appalachians, the post-Acadian geologic history is marked by the development of several rift basins that were subject to subsidence, infilling and possible dextral strike-slip faulting (Bradley, 1982; Belt, 1968). Up to $9 \mathrm{~km}$ of sediments were deposited in these basins from the middle Devonian to the Triassic (Bradley, 1982). The coarse red sediments and intercalated basalt flows of the McAras Brook Formation are typical of these post-Acadian basin fill sequences (Belt, 1968; Boucot et al., 1974; Bradley, 1982). In the stratigraphic terminology of Belt (1968), the McAras Brook Formation belongs to the "preHortan" rocks of the Maritimes together with the red beds and volcanics of the Perry, Great Bay de l'Eau, Fissett Brook, Cape John, Terrenceville and Miguasha formations. The McAras Brook Formation has been defined as the sequence of conglomerates, sandstones and basalts between an unconformity with the underlying Lower Devonian Knoydart Formation and an unconformity that truncates the highest flow (Giles and Keppie, 1977; Keppie et al., 1978). The age of the McAras Brook Formation itself is not well constrained, but Keppic et al. (1978) assign a Late Devonian age to the type section exposed near McAras Brook by correlation to a similar section at Ballantynes Cove. Late Visean (middle Mississippian) palynomorphs have been found in the overlying Martin Road Formation.

For our study we sampled the type section exposed at McAras Brook along the Arisaig coast of Nova Scotia (Fig. 1). Oriented samples from the four lava flows in the homoclinal section were collected in the field with a gasoline-powered portable drill and oriented with a Brunton compass and inclinometer. Most of the interbedded sediments are unconsolidated, and no basalt cobbles were found in the interbedded conglomerates, so additional sampling of the other lithologies is not possible. Moreover, the heavy vegetation and limited outcrop make it impossible to collect additional sites in the flows of this section. While we are cognizant of the need for a significant number of samples and sites for a reliable paleomagnetic study, in this particular case, the outcrop situation is indeed rather limited. The natural remanent 

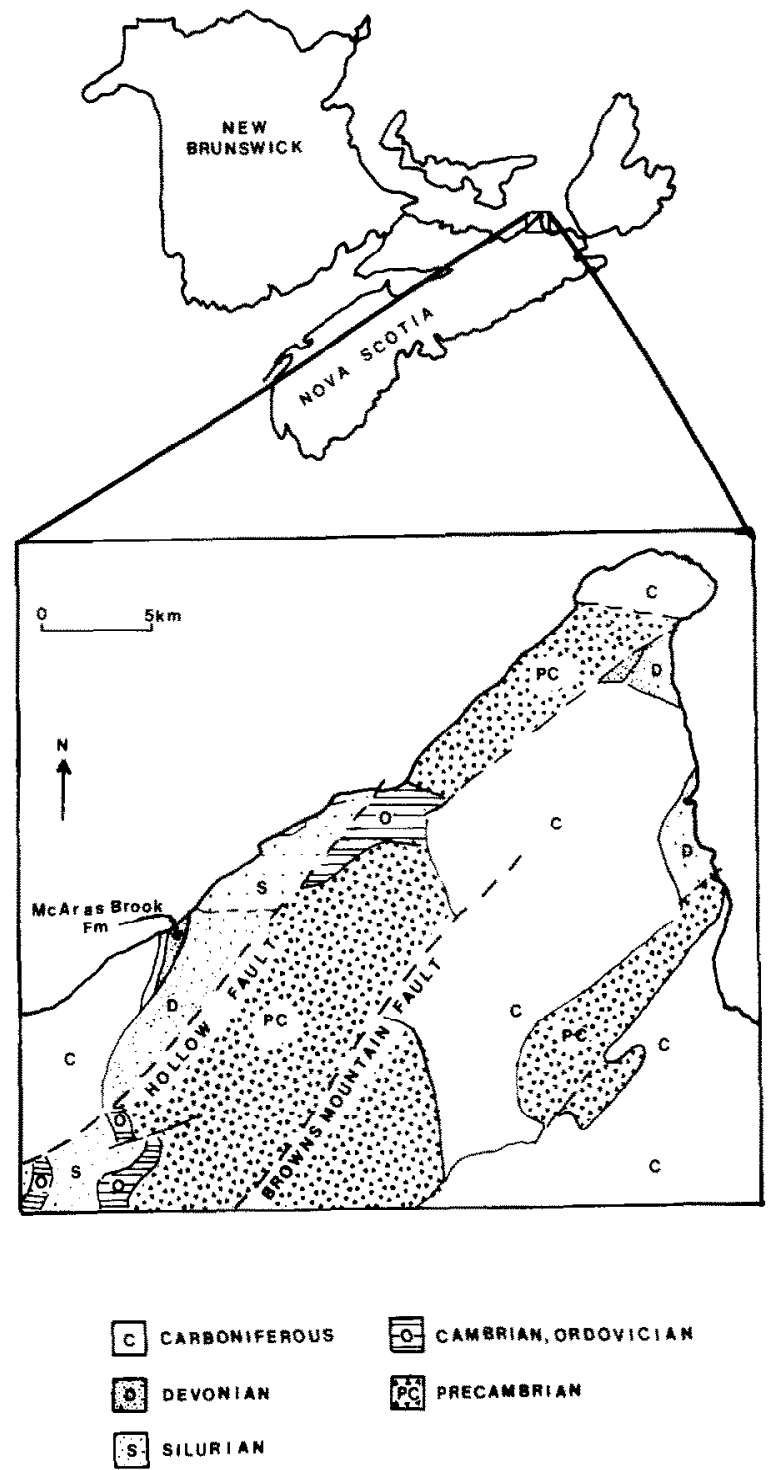

Fig. 1. Regional geology and sampling location map for the Upper Devonian McAras Brook Formation, Arisaig coast, Nova Scotia.

magnetizations (NRM) of the volcanics were measured using a Schonstedt SSM-1A spinner magnetometer at the University of Michigan. Samples were stored and treated in a magnetic field-free room to minimize the effects of viscous magnetizations. To isolate characteristic components of the NRM, stepwise thermal demagnetization experiments were carried out using a Schonstedt TSD-1 furnace. Pilot studies indicated that alternating-field demagnetization would not decompose the NRM. After visual inspection of orthogo- nal vector diagrams and equal-angle stereographic projections, best-fit demagnetization lines and planes were calculated for linear and planar demagnetization trajectories using the principal component method of Kirschvink (1980). Isothermal remanent magnetization experiments were done using a Varian Associates v-4005 Magnet Assembly with a maximum field strength of 1.4 Tesla.

\section{Paleomagnetic results}

Typical Zijderveld diagrams for the highest lava flow (sites 1-3) are shown in Fig. 2. The samples from site 3 (Figs. 2a and b) show univectorial northeasterly directions $(D / I=36 /-4$, tilt corrected) with unblocking temperatures that ranged up to $650^{\circ} \mathrm{C}$. The samples from site 2 (Figs. 2c and d) also revealed this northeasterly component at temperatures up to $580^{\circ} \mathrm{C}$. However, upon close inspection it can be seen that none of the demagnetization trajectories for site 2 decayed directly to the origin. An additional, northerly and higher-inclination component of magnetization was observed at high temperatures. Although this magnetic component constitutes a small portion of the total NRM intensity of each sample, this behavior was seen in all of the samples from site 2 . The characteristic directions for the uppermost flow are plotted in Fig. 2e and listed in Table 1. Best-fit lines were calculated for the northeasterly directions seen in site 3 and for both the low temperature (northeasterly) component and the high temperature (northerly) components of site 2 .

Characteristic Zijderveld diagrams for the lowermost lava flow (site 8) are shown in Figs. 3a, b and c. After the removal of a steep (northerly) component related to present-day field at low temperatures, many of the samples showed the presence of a southwesterly and shallow component. However, careful inspection of the demagnetization trajectories for these samples (Fig. 3d) indicates that convincingly stable endpoints were not reached during demagnetization. Because of the curvilinear nature of these Zijderveld diagrams, "best-fit planes" are more appropriate than the more traditional linear analysis (Halls, 1976; Hoffman and Day, 1978; Kirschvink, 1980). 
(a)

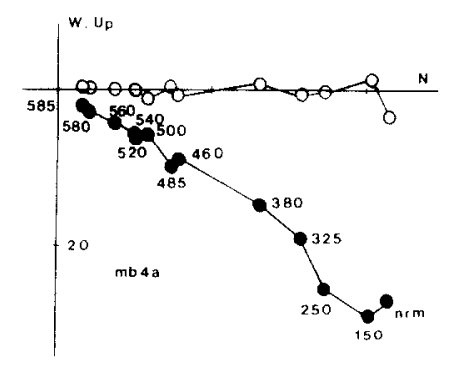

(c)

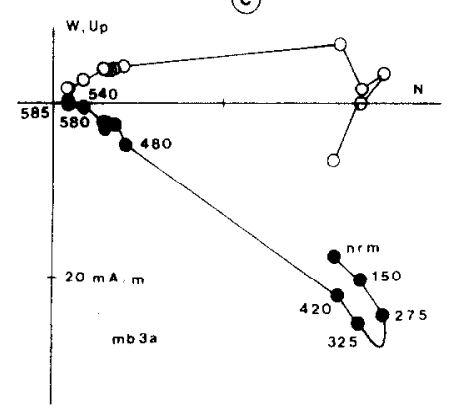

(b)
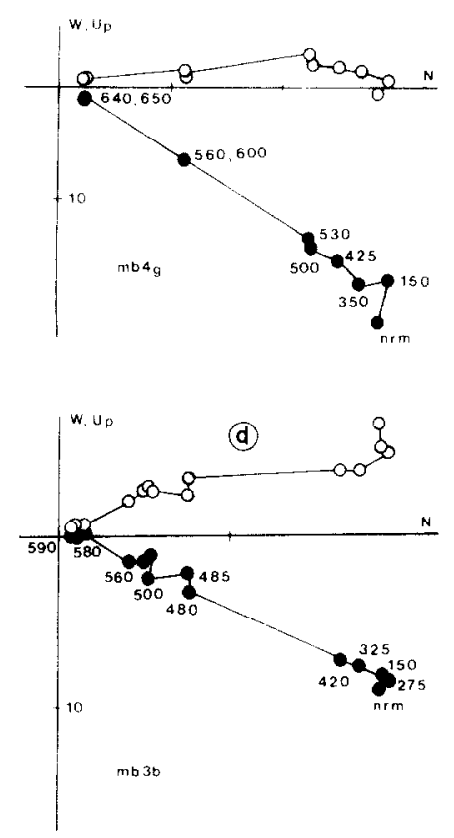

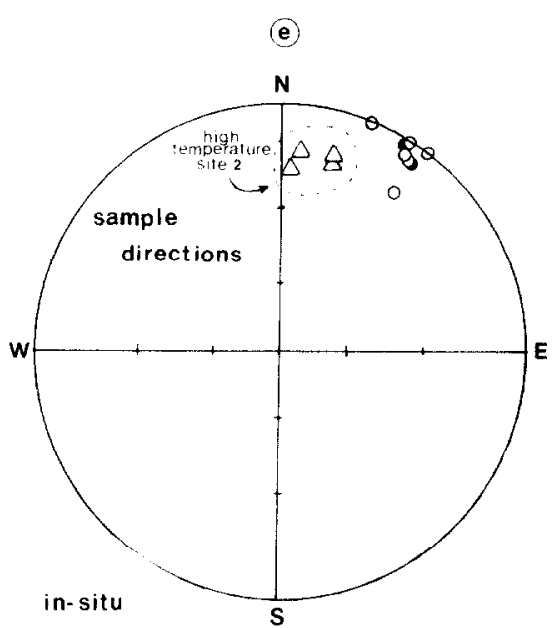

Fig. 2. Characteristic Zijderveld diagrams after correction for the tilt of the strata for thermal demagnetization of samples from site 3 ( $a$ and $b$ ) and site 2 ( $c$ and d) in the uppermost flow. Open (closed) symbols represent projections of the vector endpoints on the vertical (horizontal) planes. Intensities are labeled along the axes in $\mathrm{mA} / \mathrm{m}$. e. Equal angle stereoplot of the characteristic directions from the highest flow. Open (closed) symbols represent negative (positive) inclinations on upper (lower) hemisphere projections.

Circles are the characteristic directions from both sites and triangles are the additional high temperature components from site 2.

The stereoplot in Fig. 3d shows the southwesterly and shallow convergence of the demagnetization trajectories at high temperatures. Maximum unblocking temperatures for this site were $670^{\circ} \mathrm{C}$. The best-fit intersection direction for this site $(D / I=212 / 3$, tilt-corrected) is antipodal to the northeasterly directions seen in the highest flows.

In addition to the behavior described above, a few samples from the lowermost flow (site 8) revealed another component of magnetization. Five samples from the flow yielded demagnetization diagrams like those shown in Fig. 4a. Although it is clear that the trajectories of these samples are trending to the southeast (Fig. 4b), no characteristic direction can be calculated because the demagnetization paths are subparallel and their common intersection point is therefore poorly constrained. Because this component remains poorly constrained we will not discuss it further.

The results from the two sites (6 and 7) in the third lava flow are illustrated in Figs. 5 and 6.
Again the Zijderveld diagrams (Figures $5 \mathrm{a}$ and b, $6 \mathrm{a}, \mathrm{b}$ and c) show curvilinear paths to the origin during demagnetization and great-circle analysis was used to calculate the characteristic directions. The demagnetization paths for site 7 (Fig. 5c) show a high temperature convergence at a northerly and shallow direction $(D / I=350 /-19$, tilt corrected). Although demagnetization of the samples from site 6 also reveals a northerly direction, high temperature convergence was sometimes at the normal polarity and sometimes at the reversed polarity (Fig. 6d). The samples from site 6 carry both polarities of the direction in the same flow ( $D / I=8 /-21$, tilt corrected); these polarities are therefore without any apparent stratigraphic separation.

Finally, the samples from two sites in the second highest lava flow (sites 4 and 5) yielded univectorial Zijderveld diagrams (Fig. 7). The westerly and up directions $(D / I=269 /-34)$ were removed by $580^{\circ} \mathrm{C}$. These directions are quite 
TABLE 1

Site mean data for the McAras Brook Formation

Site coordinates: $46^{\circ} \mathrm{N}, 63^{\circ} \mathrm{W}$; strike $/$ dip $=214 / 36 \mathrm{NW}$

\begin{tabular}{|c|c|c|c|c|c|}
\hline & $n / N$ & $\begin{array}{l}\text { In-situ } \\
D / I\end{array}$ & $\begin{array}{l}\text { Tilt corrected } \\
D / I\end{array}$ & $k$ & $a_{95}$ \\
\hline \multicolumn{6}{|c|}{ Linear segments of demagnetization trajectories } \\
\hline \multicolumn{6}{|l|}{ Flow 1} \\
\hline site 1 & & \multicolumn{4}{|c|}{ only unstable magnetizations } \\
\hline site 2 (low temp) & $4 / 4$ & $32 / 0$ & $32 /-1$ & 105 & 9.0 \\
\hline site 2 (high temp) & $4 / 4$ & $10 /-15$ & $23 /-26$ & 154 & 7.4 \\
\hline site 3 & $4 / 5$ & $33 /-4$ & $36 /-4$ & 125 & 8.3 \\
\hline \multicolumn{6}{|l|}{ Flow 2} \\
\hline site 4 & $5 / 5$ & $272 /-37$ & $239 /-62$ & 284 & 4.5 \\
\hline site 5 & $4 / 5$ & $267 /-30$ & $241 /-54$ & 135 & 8.0 \\
\hline \multicolumn{6}{|l|}{ Great-circle analysis } \\
\hline \multicolumn{6}{|l|}{ Flow 3} \\
\hline site 6 & $6 / 7$ & $1 /-3$ & $8 /-21$ & 633 & 5.5 \\
\hline site 7 & $6 / 11$ & $347 / 7$ & $350 /-19$ & 100 & 22.9 \\
\hline \multicolumn{6}{|l|}{ Flow 4} \\
\hline \multirow[t]{3}{*}{ site 8} & $8 / 16$ & $211 /-1$ & $212 / 3$ & 127 & 9.3 \\
\hline & & & \multicolumn{3}{|l|}{ paleopoles } \\
\hline & & & in situ & & tilt corrected \\
\hline \multicolumn{6}{|c|}{ Mean of the site means } \\
\hline \multicolumn{6}{|c|}{ Component A (sites 2, 3, 8) } \\
\hline$D / I$ & $212 / 1$ & $213 / 2$ & $36^{\circ} \mathrm{N}, 76^{\circ} \mathrm{E}$ & & $35^{\circ} \mathrm{N}, 76^{\circ} \mathrm{E}$ \\
\hline$k$ & 821 & 821 & & & \\
\hline$a_{95}$ & 4.3 & 4.3 & & & \\
\hline \multicolumn{6}{|c|}{ Component B (sites 6,7 , and high temp 2) } \\
\hline$D / I$ & $359 /-4$ & $7 /-23$ & $46^{\circ} \mathrm{N}, 116^{\circ} \mathrm{E}$ & & $32^{\circ} \mathrm{N}, 109^{\circ} \mathrm{E}$ \\
\hline$k$ & 26 & 27 & & & \\
\hline$a_{95}$ & 24.7 & 24.1 & & & \\
\hline \multicolumn{6}{|c|}{ Component $C$ (sites 4,5 ) } \\
\hline$D / I$ & $269 /-34$ & $240 /-58$ & $14^{\circ} \mathrm{N}, 15^{\circ} \mathrm{E}$ & & $46^{\circ} \mathrm{N}, 14^{\circ} \mathrm{E}$ \\
\hline
\end{tabular}

$n / N$ is the ratio of number of samples used to the number of samples analysed; $D / I$ is the declination/inclination; $k$ and $a_{95}$ are the statistical parameters associated with the means.

different from any Late Paleozoic or younger directions expected for Nova Scotia and can only be described as highly anomalous.

In summary, thermal demagnetization of basalt samples from four lava flows in the Upper Devonian McAras Brook Formation has revealed complex paleomagnetic results. Site means are listed in Table 1 and plotted in Fig. 8 (all directions are inverted to normal polarities). Two dual polarity magnetizations can be seen in three of the four flows. A northeasterly (southwesterly) direction is seen in samples from the highest and lowest flow. The northeasterly direction is seen as univectorial directions in samples from site 3 (flow 1) and as one of the two components of magnetization in the samples from site 2 (flow 1). The antipodal southwesterly component was observed in the samples from the lowest flow (site 8). The 

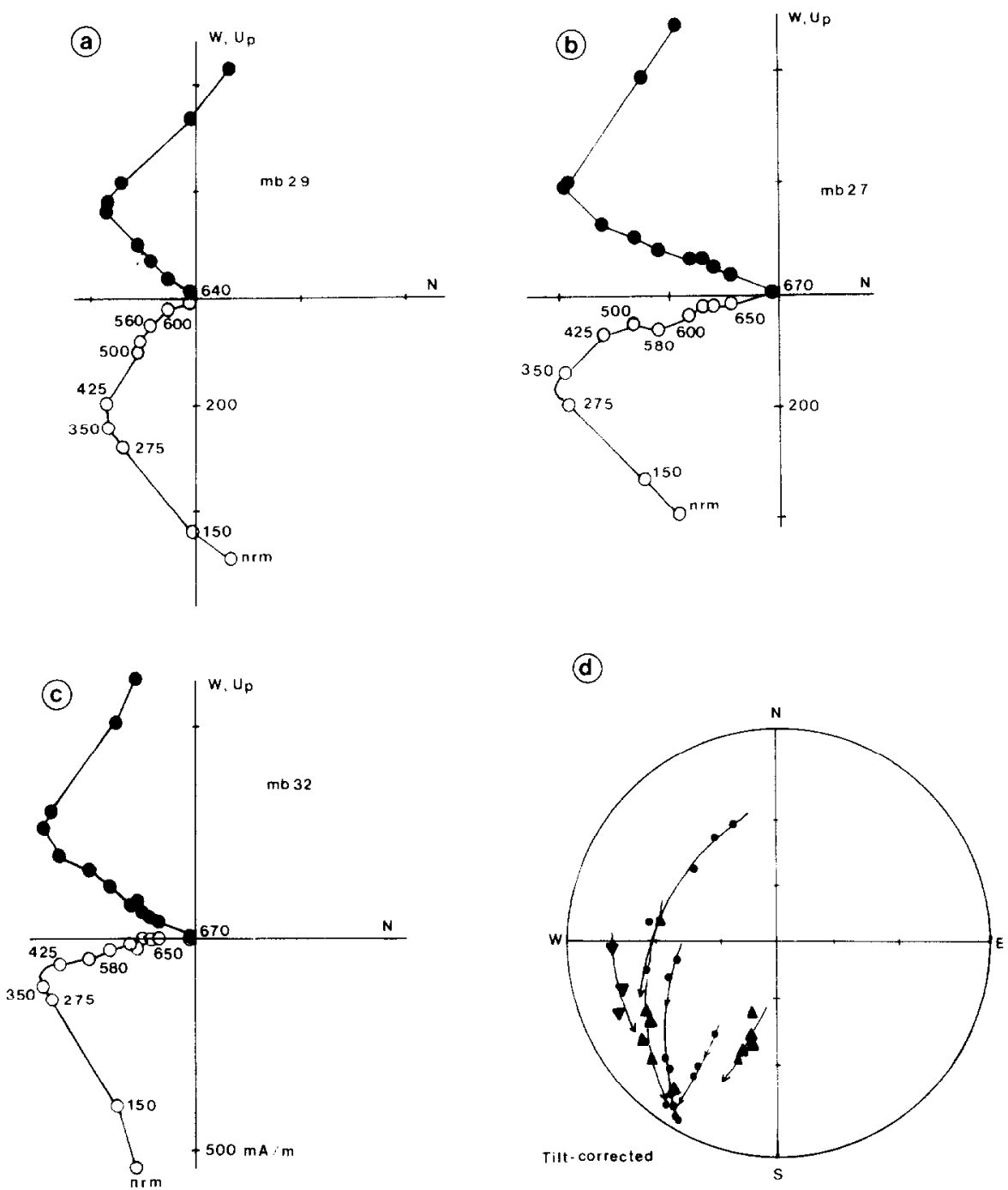

Fig. 3. Typical demagnetization results from the lowest flow after correction for the tilt of the strata. a-c. Zijderveld diagrams with symbols as in Fig. 2. d. Equal angle stereoplot with representative demagnetization trajectories for thermal treatment of individual samples. Symbols are as in Fig. 2. Different symbols (triangles and circles) are used to keep distinct the demagnetization measurements of individual samples.

northerly (southerly) component of magnetization is seen as a high temperature component in the samples from one site in the highest flow (site 2) and as the convergence point for the demagnetization great circles in the third lava flow (sites 6 and 7). Great-circle analysis of site 6 yields high temperature convergence at both normal and reversed polarities without any apparent stratigraphic separation. Evidence for the simultaneous presence of both magnetic components, i.e. the NE-SW and the $\mathrm{N}-\mathrm{S}$ direction, within individual samples can be seen in the Zijderveld diagrams in Figs. $2 \mathrm{c}$ and $\mathrm{d}$ and in a few samples from the lowermost flows (e.g. Figs. $4 c$ and perhaps $5 b$ ). Several samples from the lowermost flow showed a southeasterly rather than (north -)south component of magnetization. However, because the demagnetization paths are subparallel, this southeasterly component remains poorly constrained and will not be included in the results. Finally, samples from the 
(a)
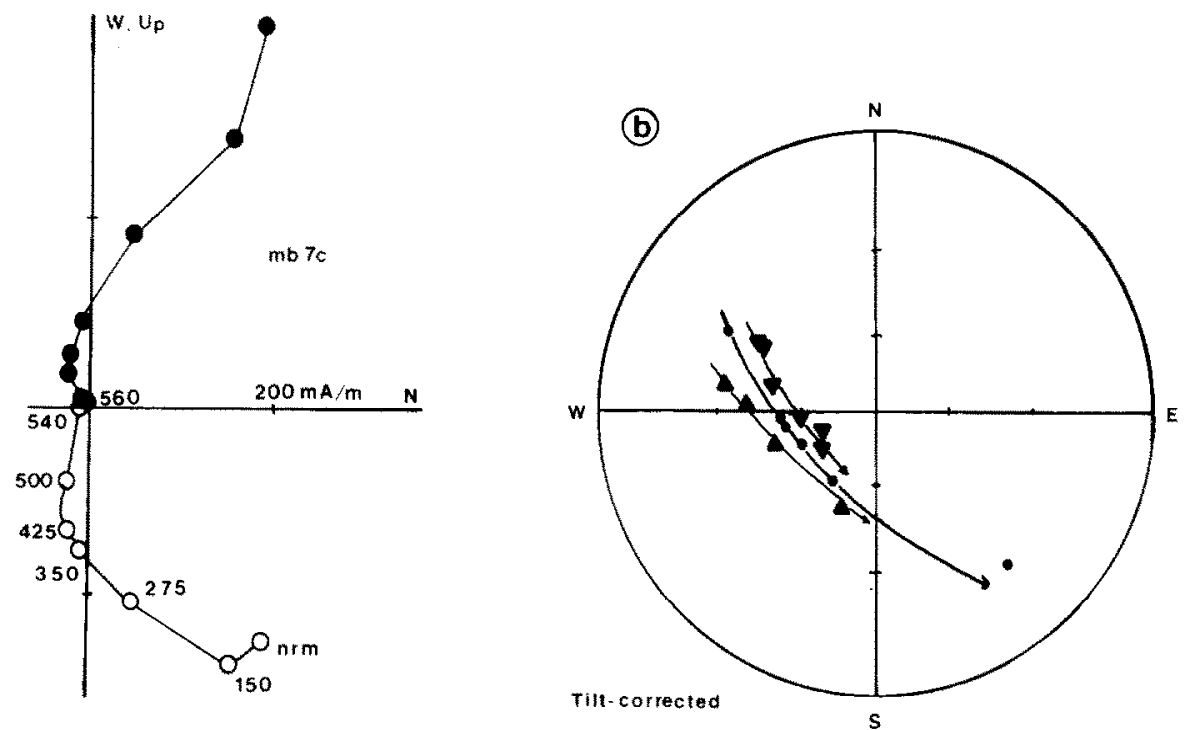

Fig. 4. Demagnetization diagrams showing the additional component of magnetization seen in the lowermost flow. a. Typical Zijderveld diagram. b. Equal angle projection of individual demagnetization trajectories. Symbols as in previous figures.

second highest flow revealed univectorial, westerly and up magnetic directions.

\section{Magnetic mineralogy}

The unblocking temperatures for thermal demagnetization of the McAras Brook Formation illustrated in the Zijderveld diagrams in Figs. 2-7 provide some constraint on the carriers of the NRM. Most of the samples from the highest and two lowest flows have unblocking temperatures that range up to $650^{\circ} \mathrm{C}$ which indicates that hematite is carrying all or part of the NRM. However, in samples from second highest flow
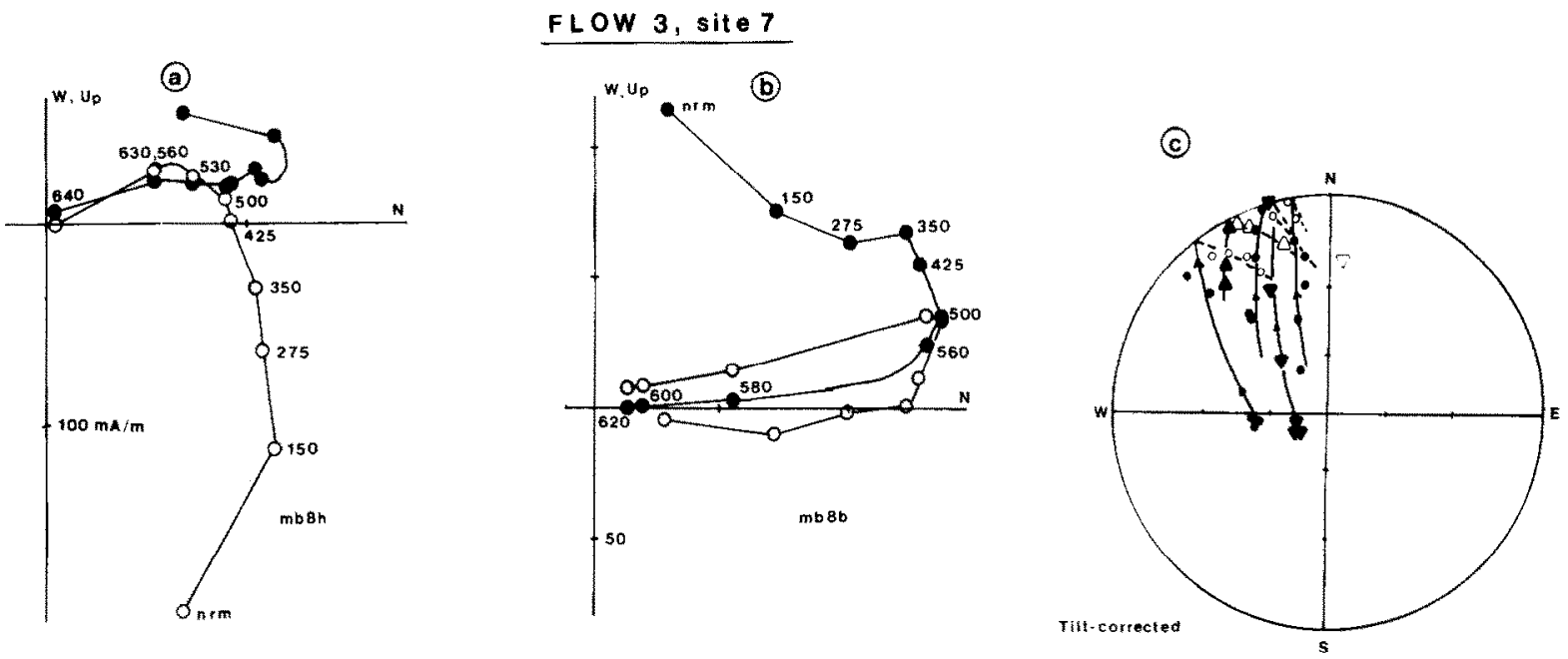

Fig. 5. Demagnetization results from site 7 in the third lava flow. a, b. Typical Zijderveld diagrams. c. Typical demagnetization trajectories. Symbols as in previous figures. 

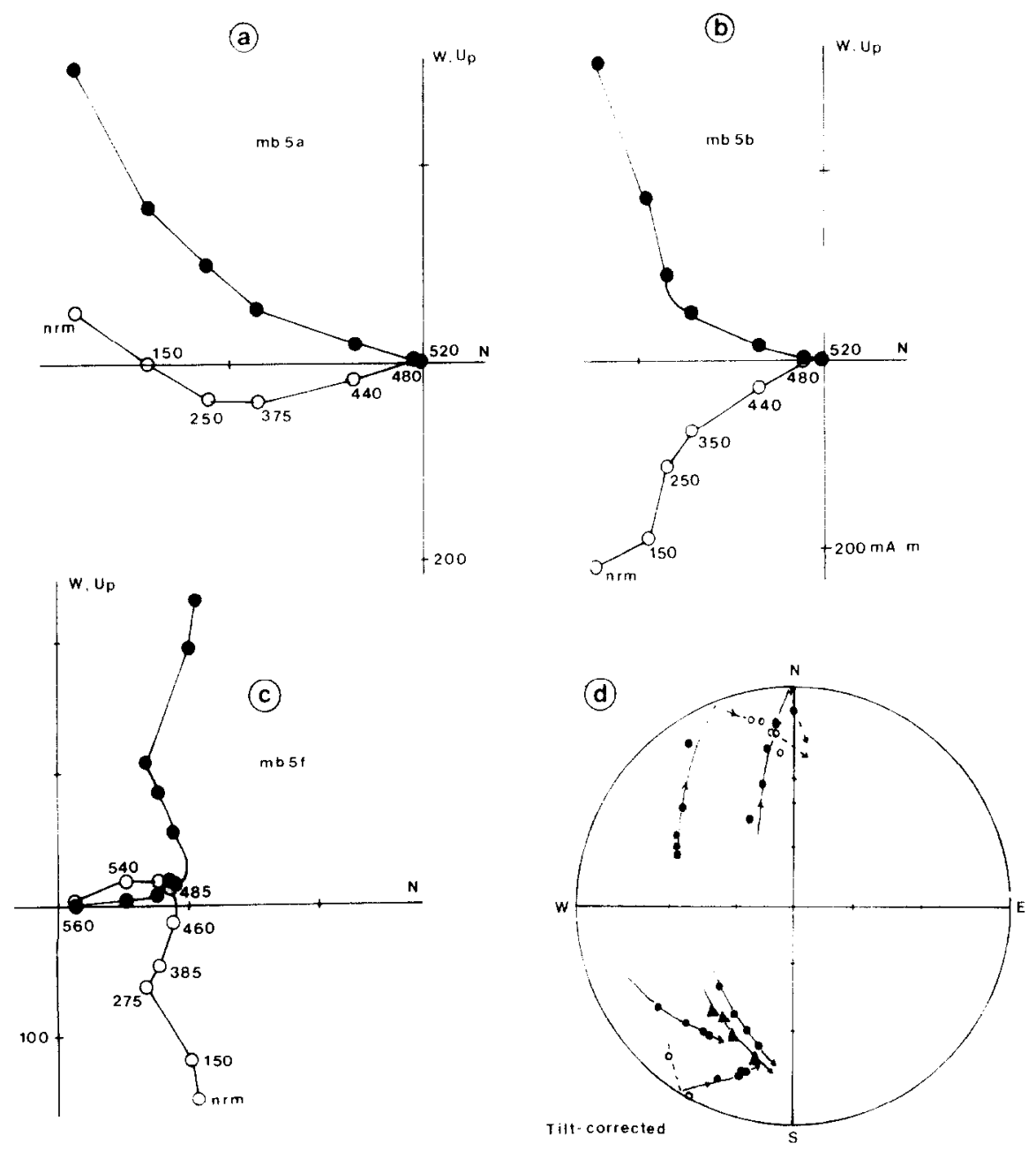

Fig. 6. Dual polarity results from site 6 in the third lava flow. a c. Zijderveld diagrams. d. Demagnetization trajectories. Symbols as in previous figures.

and from site 6 in the third flow, the NRM was removed by $580^{\circ} \mathrm{C}$ which suggests that (titano-) magnetite may be the magnetic carrier.

In order to further investigate the magnetic mineralogy of the basalts, isothermal remanent magnetization (IRM) experiments were undertaken. Typical IRM acquisition curves for each flow are shown in Fig. 9. Samples from the two highest flows did not saturate by 0.3 Tesla which confirms hematite as a magnetic carrier. In contrast, samples from the lower two flows saturate below 0.3 Tesla and have much stronger saturation intensities which suggests that (titano-)mag- netite is a predominant magnetic mineral in these samples. Reflected-light microscopy (with magnification up to $400 \times$ ) also reveals a complex oxide mineralogy. Ilmenite grains with small exsolution lamellae are the most common oxide grains in the rocks, but some hematite is also present. Most of the oxide grains are not pristine and show textural evidence of oxidation. Although we are unable to conclusively determine which magnetic phases in the rocks are carriers of the NRM, we suspect that after the extrusion of the basalts, low temperature oxidation of the original magnetic phases occurred during subaerial ex- 

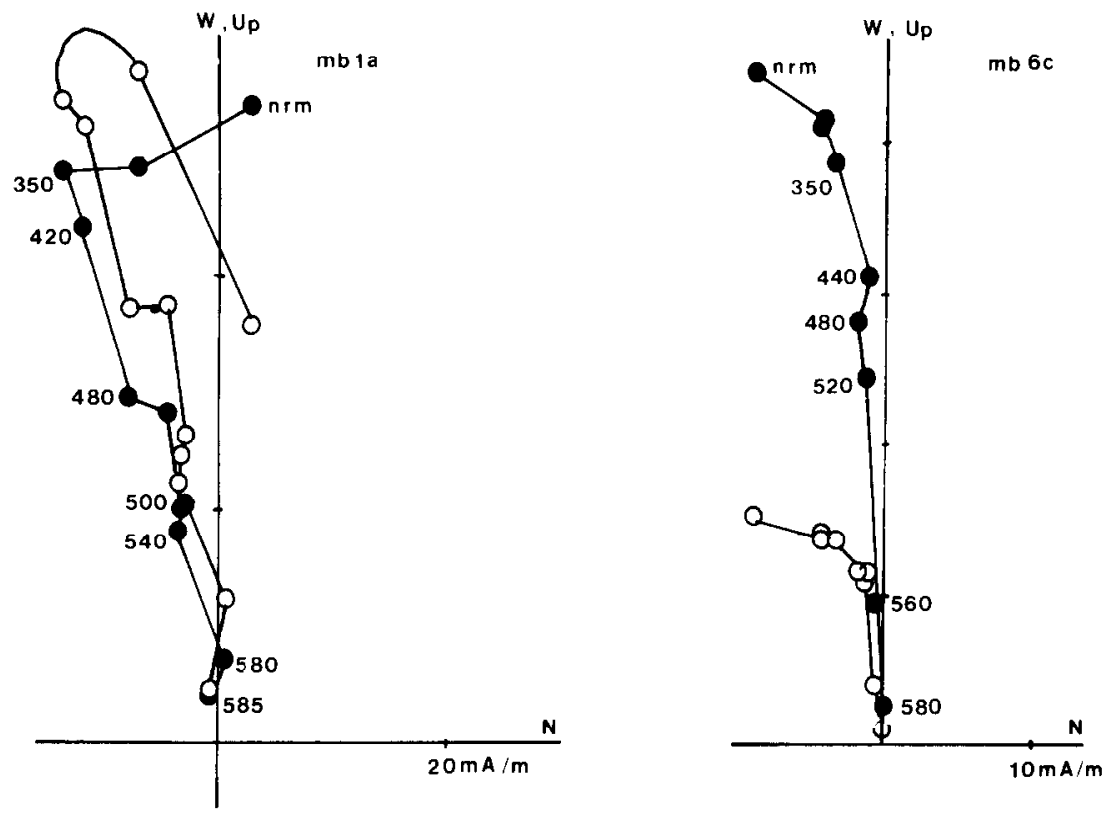

Fig. 7. Zijderveld diagrams showing the westerly directions of the second highest lava flow. Symbols as in previous figures.

posure and subsequent burial in the post-Acadian rift basin. We interpret the secondary magnetic directions carried by the volcanics of the McAras Brook Formation as low temperature (thermo-?) chemical overprints.

\section{Interpretation of the results}

The paleomagnetic results for the volcanics of the McAras Brook Formation are summarized in Table 1, the site means are plotted in Fig. 8 and

site means
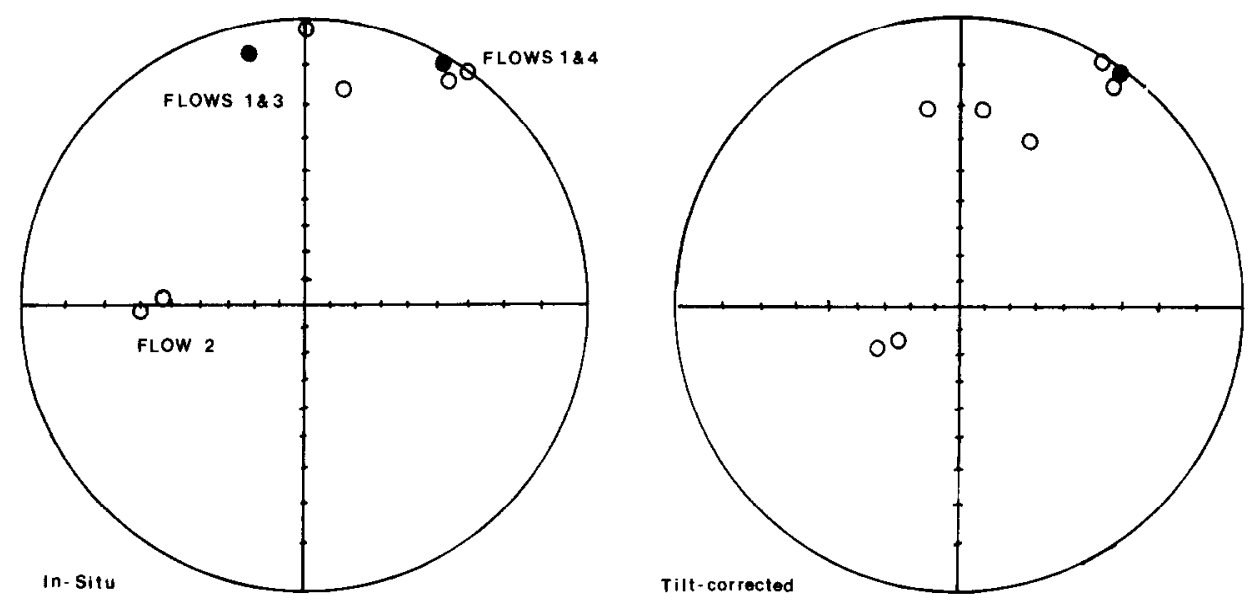

Mc Aras Brook Formation

Fig. 8. Equal angle projections of the site means for the McAras Brook Formation. All directions are plotted as normal polarities. Symbols as in previous figures. 
a

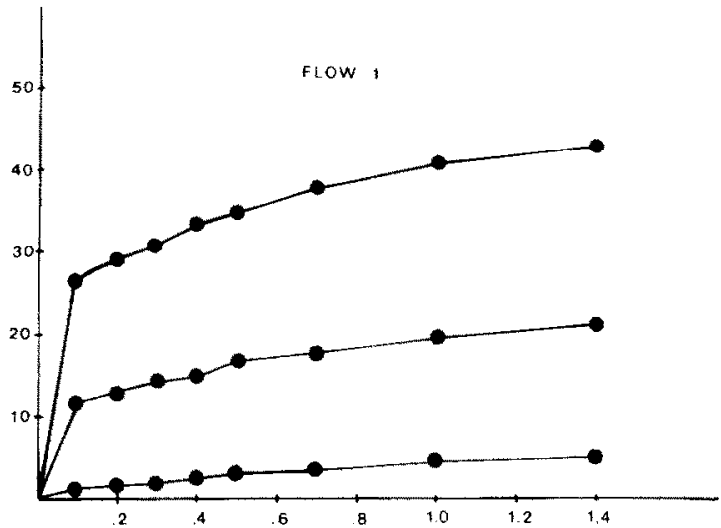

c

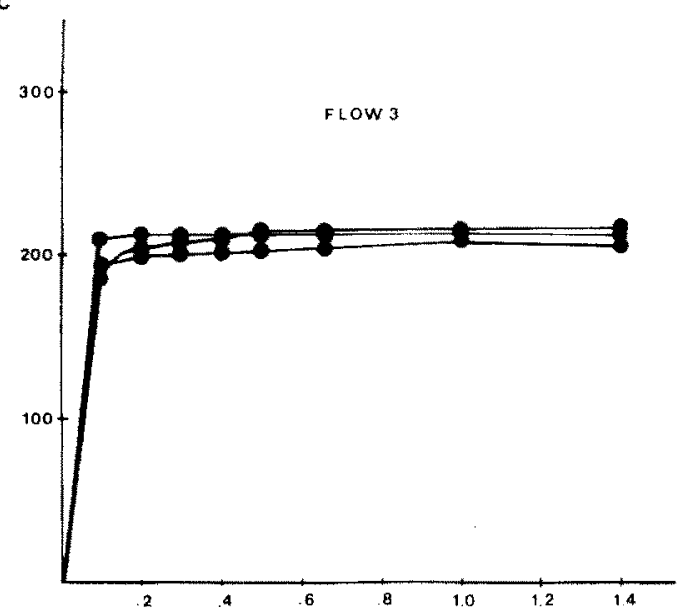

b
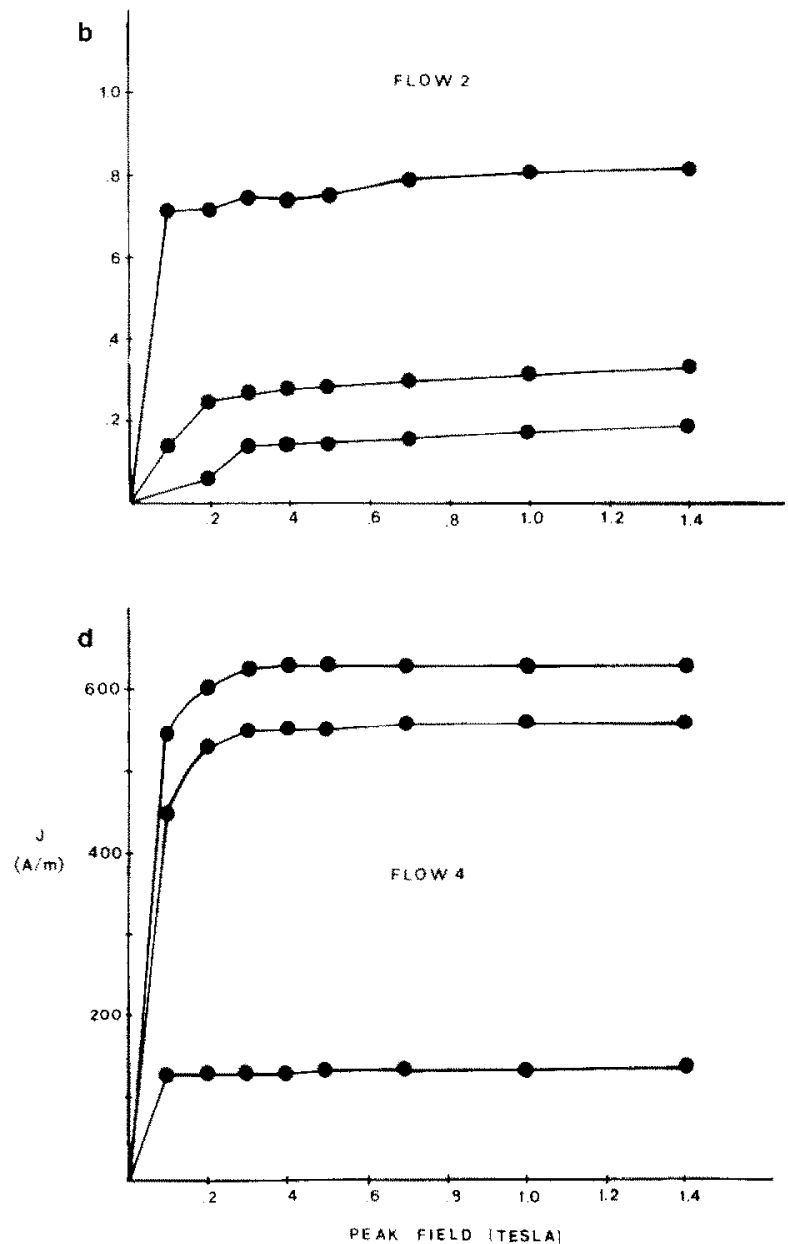

Fig. 9. Isothermal remanent acquisition curves (IRM) for (a) highest flow, (b) second flow, (c) third flow and (d) fourth flow.

the corresponding paleopoles for the directions seen in the McAras Brook Formation are plotted in Fig. 10 along with previously published Devonian, Carboniferous and Permian poles for North America.

Two dual-polarity magnetizations are seen in the lava flows. Since both components can be seen superimposed in individual samples, one of these directions must be secondary. The northeasterly direction appears to have stratigraphically controlled reversals, whereas the dual polarities of the northerly direction have no apparent stratigraphic separation; it is likely, therefore, that the northeasterly direction is primary and the northerly component is secondary.

Two of the four flows yield the northeasterly (or southwesterly) and shallow direction whose corresponding paleopole $\left(34^{\circ} \mathrm{N}, 75^{\circ} \mathrm{E}\right)$ is similar to previously published Devonian poles for North America. Unfortunately no independent stability test is available to constrain the age of this magnetization. Since the observed directions are antipodal, we conclude that the magnetic directions are not contaminated by an overprint. Furthermore, application of the structural correction does not significantly change the direction $(213 / 1$, insitu, $214 / 1$, tilt-corrected). We interpret the northeasterly component of magnetization as primary (Late Devonian).

The more northerly and shallow direction is seen as a magnetic component in samples from two of the lava flows. This direction is seen most clearly in the samples from the third flow (Figs. 5 and 6). But we also could determine this direction as a small, high temperature component in the samples from site 2 in the highest flow (Figs. $2 \mathrm{c}$ 


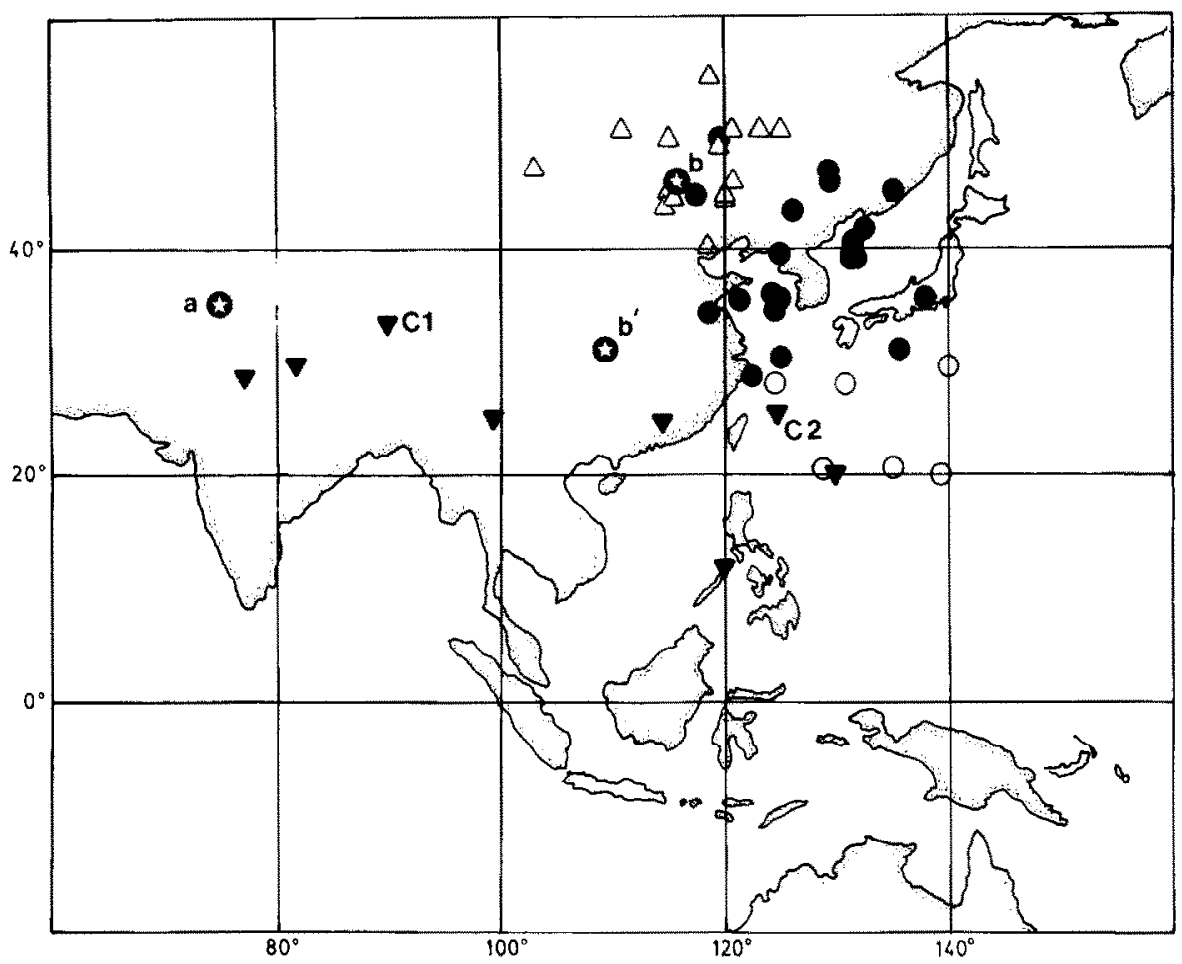

Fig. 10. Devonian through Permian paleopoles for North America. Poles taken from lists in Van der Voo (1988), Johnson and Van der Voo (1988) and Stearns and Van der Voo (1987). Open triangles are Permian poles, closed circles Latc Carbonifcrous, open circles Early-Middle Carboniferous poles, and closed triangles are Devonian poles. The encircled stars are the poles calculated from the results of this study with 'denoting the tilt-corrected pole. $\mathrm{Cl}$ and $\mathrm{C} 2$ are the results from the Devonian Catskill Formation.

and d). The dual polarity magnetizations of the third flow, which occur without any stratigraphic separation, are unlikely to be caused by self-reversal of the magnetic minerals (Stacey and Banerjee, 1974; O'Reilly, 1984). Rather, they represent acquisition of magnetization over a period of time during which the Earth's field was reversing. Comparison of the corresponding paleopole with the reference APWP in Fig. 10 also suggests that this paleopole is younger than the pole for the northeasterly component. Although the in-situ paleopole plots near the Permian section of the APWP, most of the directions are of normal polarity and therefore these directions are unlikely to represent a direction acquired during the Kiaman reversed chron. In fact, dual polarity magnetizations have been reported in several similar aged rocks from the Canadian Maritime Province (e.g. Seguin et al., 1982; Roy and Morris, 1983; Johnson and Van der Voo, 1988). Furthermore, Roy and Morris (1983) suggest that dual polarity magnetizations can be used as chronostratigraphic markers since field reversals are common in the Early Carboniferous and absent from the Late Carboniferous rock record. We suggest then that these northerly (southerly) directions are secondary magnetizations which were acquired in the Late Devonian to possibly earliest Carboniferous, before tilting of the rocks. Thus, we prefer the tilt-corrected pole ( $b^{\prime}$ in Fig. 10).

Finally, the westerly and up direction from the two sites in the second highest lava flow is highly deviatory. These samples only carried univectorial magnetizations. The corresponding paleopoles $\left(14^{\circ} \mathrm{N}, 15^{\circ} \mathrm{E}\right.$, in-situ, $46^{\circ} \mathrm{N}, 14^{\circ} \mathrm{E}$, tilt corrected) are dissimilar to any existing Phanerozoic pole for North America. The directions cannot be explained by tectonic rotation, since all of the flows have similar strike and dips. It is possible that these directions are related to a transitional field during a reversal since stratigraphically the flow is between the normal (northeasterly) magnetiza- 
tions of the highest flow and the reversed (southwesterly) magnetization of the lowermost flow.

An important implication of the results from the McAras Brook Formation is that the samples from the same location yield paleomagnetic results that generate paleopoles that are of the same latitude, but vary in longitude. In fact, they define a path that coincides with the locations of the available Devonian paleopoles for North America (see Fig. 10). Because both magnetic components are seen in individual samples, the magnetizations are clearly of different age. Although systematic variation in declinations from the Catskill Formation around the Pennsylvania salient have been used to support oroclinal bending in the Appalachians (Miller and Kent, 1986a, b, poles $\mathrm{Cl}$ and $\mathrm{C} 2$ in Fig. 10), our data suggest the existence of significant apparent polar wander. This would mean that the path defined by the available paleopoles documents a clockwise rotation of the North American plate as a whole over approximately $45^{\circ}$ from the early Devonian to the early Carboniferous. Until techniques are developed to more accurately date the acquisition of magnetization in rocks (i.e. more precisely than pre-, syn- or post-folding events while the orogenic phases themselves may be poorly dated), it will remain difficult to determine whether all the available Devono-Carboniferous poles are in fact chronologically sequential and therefore do document systematic apparent polar wander.

Although at first glance the complex nature of the paleomagnetic results from the Upper Devonian McAras Brook Formation raises the suspicion that these rocks may not be good recorders of the past geomagnetic field, the results are nonetheless quite interesting and apparently not uncommon for similarly aged rocks from the Canadian Maritime Provinces. Unfortunately, we lack a field stability test to date the magnetization of the Upper Devonian McAras Brook Formation. Therefore the results cannot be used to generate a quality reference paleopole. Instead we have used comparisons to the existing North American Apparent Polar Path to support our interpretations on the ages of the magnetic directions observed in the McAras Brook Formation. In Fig. 10 both the in-situ and tilt corrected paleopoles are plotted for each direction. In each case we have interpreted the directions as pre-folding. We feel that the similarity of these two components to other published results strongly suggests that these magnetizations are representative of the Late Devonian (to Early Carboniferous?) geomagnetic field. It appears that this is a period of rapid apparent polar wander, with frequent field reversals. It is not surprising then, that rocks acquiring secondary, low temperature magnetizations during this time interval should yield such complex magnetic results.

\section{Conclusions}

A paleomagnetic investigation of the Upper Devonian McAras Brook Formation has yielded complex paleomagnetic results. Thermal demagnetization of samples from three of the four lava flows revealed two dual polarity directions that appear to be Devonian to possibly earliest Carboniferous in age. The presence of stratigraphically separated polarities in addition to comparison with previously published North American data suggests that a northeasterly and shallow direction is primary. Both polarities of a northerly and shallow direction occur without apparent stratigraphic separation; this magnetization is interpreted as a secondary magnetization acquired before tilting of the rocks. The presence of dual polarities indicates that this secondary direction was acquired during a period of magnetic field reversals and that the magnetization is likely to be pre-Kiaman. The anomalous westerly magnetizations of the second highest flow remain unexplained, although they may represent directions acquired during a transitional field. IRM experiments, unblocking temperatures and thinsection petrography indicate that the NRM is carried by both hematite and (titano-)magnetite. It is likely that the secondary magnetizations were acquired during a low-temperature oxidation of the basalts during the infilling of a post-Acadian rift basin. Our results indicate that some of the longitudinal spread in the currently available Devonian-Early Carboniferous paleopoles is due to the clockwise rotation of the North American plate as a whole rather than by localized tectonic 
rotations of individual sites.

\section{Acknowledgments}

We thank William Farrand for his help collecting the samples, Annie Kersting for her help with the thin section analysis and Aden Medel for his endless hours in the laboratory measuring samples. A review by Rex Johnson improved the quality of the manuscript. This research was supported by the National Science Foundation grant EAR 84-07007.

\section{References}

Belt, E.S., 1968. Post-Acadian rifts and related facies, eastern Canada. In: E. Zen, W.S. White, J.B. Hadley and J.B. Thompson, Jr. (Editors), Studies of Appalachian Geology: Northern and Maritime. Interscience, New York, pp. 95-113.

Boucot, A.J., Dewey, J.F., Dineley, D.L., Fletcher, R., Fyson, W.K., Griffin, J.G., Hickox, C.F., McKerrow, W.S. and Ziegler, A.M., 1974. Geology of the Arisaig Area, Antigonish County, Nova Scotia. Geol. Soc. Am., Spec. Pap., 139: $191 \mathrm{pp}$.

Bradley, D.C., 1982. Subsidence in Late Paleozoic basins in the northern Appalachians. Tectonics, 1: 107-123.

Dankers, P., 1982. Implications of Early Devonian poles from the Canadian Archipelago for the North American apparent polar wander path. Can. J. Earth Sci., 19: 1802-1809.

Giles, P.S. and Keppie, J.D., 1977. Redefinition of the McAras Brook Formation, Cape George, Nova Scotia. Nova Scotia Dep. Mines Rep., 78-1: 83.

Halls, II.C., 1976. A least squares method to find a remanence direction from converging remagnetization circles. Geophys. J.R. Astron. Soc., 45: 297-304.

Hillhouse, J.W. and McWilliams, M.O., 1987. Application of paleomagnetism to accretionary tectonics and structural geology. Rev. Geophys., 25: 951-959.

Hoffman, K.A. and Day, R., 1978. Separation of multicomponent NRM: a general method. Earth Planet. Sci. Lett., 40: 433-438.
Johnson, R.J.E. and Van der Voo, R., 1988. Dual-Polarity Early Carboniferous remagnetization of the Fissett Brook Formation, Cape Breton Island, Nova Scotia. Geophys. J. R. Astron. Soc., in press.

Kent, D.V. and May, S.R., 1987. Polar wander and the reference pole controversies. Rev. Geophys., 25: 961-970.

Keppie, J.D., Giles, P.S. and Boehner, R.C., 1978. Some Middle Devonian to Lower Carboniferous rocks of Cape George, Nova Scotia. Nova Scotia Dep. Mines Rep., 79-1, Pap. 78-4: 85-86.

Kirschvink, J.L., 1980. The least-squares line and plane analysis of paleomagnetic data. Geoplys. J.R. Astron. Soc., 62: 699-718.

Miller, J. and Kent, D.V., 1986a. Synfolding and prefolding magnetizations in the Upper Devonian Catskill Formation of eastern Pennsylvania: Implications for the tectonic history of Acadia. J. Geophys. Res., 91: 12,791-12,803.

Miller, J. and Kent, D.V., 1986b. Paleomagnetism of the Upper Devonian Catskill Formation from the southern limb of the Pennsylvania Salient: Possible evidence of oroclinal rotation. Geophys. Res. Lett., 13: 1173-1176.

O'Reilly, W.O., 1984. Rock and Mineral Magnetism. Blackie, Glasgow, $220 \mathrm{pp}$.

Roy, J.L. and Morris, W.A., 1983. A review of paleomagnetic results from the Carboniferous of North America: the concept of Carboniferous geomagnetic field horizon markers. Earth Planet. Sci. Lett., 65: 167-181.

Seguin, M.K., Rao, K.V. and Pineault, R., 1982. Paleomagnetic study of Devonian rocks from Ste. Cecile-St. Sebastien region, Quebec, Appalachians. J. Geophys. Res., 87: $7853-7864$.

Stacey, F.D. and Banerjee, S.K., 1974. The Physical Principles of Rock Magnetism. Elsevier, Amsterdam, $195 \mathrm{pp}$.

Stearns, C. and Van der Voo, R., 1987. A paleomagnetic reinvestigation of the Upper Devonian Perry Formation: evidence for Late Paleozoic remagnetization. Earth Planet. Sci. Lett., 86: 27-38.

Van der Voo, R., 1988. Paleomagnetism of continental North America: the craton, its margins and the Appalachian Belt. In: Geophysical Framework of the Continental United States. Geol. Soc. Am., Mem., in press.

Zijderveld, J.D.A., 1967. A.C. demagnetization of rocks: analysis of results. In: D.W. Collison, K.M. Creer and S.K. Runcorn (Editors), Methods of Paleomagnetism. Elsevier, Amsterdam, pp. 254-286. 